\title{
Factors Those Influence the Job Satisfaction of School Teachers Who Work for Different Schools Situated in Sylhet City, Bangladesh
}

\author{
Anwar Ahmad Arif ${ }^{1}$ \\ ${ }^{I}$ (Department of Business Administration, Leading University, Bangladesh)
}

\begin{abstract}
This Study is under taken to find out the factors that influence the job satisfaction of school teachers who work for different school situated in Sylhet City. Data have been collected from the teachers of different schools situated in Sylhet city. Structured, close ended questionnaire has been used to collect data adopting cluster sampling method. Data have analyzed and interpreted through pie charts using SPSS. It is found that few nonmonetary factors influence the teachers' job satisfaction.
\end{abstract}

Keywords: Job satisfaction, teachers' job satisfaction, Sylhet city

\section{Introduction}

Job satisfaction has a significant association with the satisfaction of the life (Buitendach \& Dewitte, 2005). It is also associated with organizational commitment and job performance (Cullinah, 2005). Therefore, most provably, Job satisfaction is the most frequently and extensively researched subject in organizational behavior (Judge \& Church, 2000). Almost all the motivational theories signify that the satisfaction of employees impacts performance of the employees. Various extensive and expensive researches show that job satisfaction is related to many factors like motivation, productivity, and general life satisfaction (Landy, 1978). Generally people like to introduce themselves by their occupations. They like to be called as a doctor, lawyer, or teacher (Judge \& Klinger, 2007). Teaching is, a little, a different type occupation than others. Now a day, in twenty first century, teachers are plying vital role for ensuring the quality education. That is why; researchers are paying more attention to the job satisfaction of the teachers (Bowen \& Radhakrishna, 1991). Teachers are significantly responsible for making and leading young people succeed in productive lives. Teachers' effectiveness has a very strong influence on their students (Hattie 2003). It is broadly considered that the quality of teachers is 'the single-most' important factor for inspiring and influencing young people in schools, in further education, in work, and in life (OECD 2005). Thus, researchers are trying to find out the factors that ensures job satisfaction of teachers.

Sylhet is a historic metropolitan city situated in the northeastern part of Bangladesh. It is one of the oldest inhabited places in the region. The famous Chinese scholar Xuán Zàng visited Sylhet in 640 AD. From $10^{\text {th }}$ century, Sylhet, then called Srihatta, town was the major center of the territory (Abu Iman 1967). In 14 ${ }^{\text {th }}$ century, Shah Jalal, the Muslim religious leader, conquered Sylhet over local Raja and introduced Islam to the people. Famous tourist Ibn Batuta visited Shah Jalal in Sylhet in 1346 (Abdul Karim, 1992 ). Sylhet whiteness thousands events and incidents though out the last centuries. It is said that Sylhet is the land of the rich people in Bangladesh (Katy Gardner, 1995).

In 1867 Sylhet was upgraded in to Municipal Town (Banglapedia). Nearly one and half century later, in April, 2001, the town was made the city under Sylhet City Corporation Act 2001. Finally in March 2009, the government declared Sylhet as a Metropolitan City. The total area of the city is $26.50^{2} \mathrm{Km}$. The total population of the city is some $5,00,000$.

In end of 2016, there is little number of schools at every single area of the city. Some of them are very famous and the rest of them are average. All around the world, there are many studies on the motivation and job satisfaction of school teachers. Most of the studies are on nonprofit making schools (Wu, Z. 2010). This study includes teachers of both profit making and nonprofit making schools.

\section{Background of The Study}

In Sylhet, it is seen that there are a good number of private schools. Most of them are English medium and provide tuition up to higher secondary level. These schools employ highly educated smart people who are fluent in English. In some cases, we see they employ students of tertiary level institutions to teach their pupil. Many of these schools are performing outstanding result and hence, we assume that the teachers are highly satisfied with their job.

At the same time, for attaining school's goals the school authorities mostly need teachers who are satisfied with their job (Noordin and Jusoff, 2009). As job satisfaction is described as the physical and mental 
comfort of the employee and it is important to the job related behavior and productivity, now a day, it is one of the most important topics to study on (Spector, 1997).

\section{Research Problem}

In this study, it is searched to find out the factors those make teachers of different schools located in Sylhet City satisfied to their job.

\section{Literature Review}

Job satisfaction is a relative issue. As peoples attitude are different from each other, their behavior towards any particular object is different as well. And, thus, the satisfaction level of different individual is different than others. Similarly, level of job satisfaction determines an employee's behavior towards his/her job. Consequently, level of job satisfaction determines the level of total satisfaction of the employee's life (Buitendach \& Dewitte, 2005). For many reasons, job satisfaction plays vital role in employee's behavior. Some of the reasons are like - employee performance, employee absenteeism, and employee turnover. On the other hand, satisfaction of en employee is very much vital for retaining the capable employees in organization. In case of the relationship between job satisfaction and employee performance, we see, there is a long historical debate. The debate started from the Hawthorne studies. These studies took place in between 1924 - 1933. From then, as a result of critically investigated researchers, we find a positive relationship between job satisfaction and employee job performance (Naidu, 1996). In 1985, Iaffaldano and Muchinsky found a very week relation between job satisfaction and employee job performance. In 1988, Dennis W. Organ argued that, if we consider organizational behavior as part of employee job performance, we shall find an improved relationship between job satisfaction and job performance. Michelle Jones, in 2006 showed that there is a positive correlation between job satisfaction and job performance, although it is a week relation (Jones, 2006).

In Industrial Psychology, it is one of the widely investigated issues to find out the relationship job satisfaction and Employee absenteeism (Cheloha, \& Farr, 1980). It very much obvious that if an individual do not find any interest in his / her job he / she may not like to do the same job continuously. That is why he / she may very often call for sick leave and will find other opportunities (Johns, 1997). Dissatisfied employees always look for new job and if they find a new one they just simply give-up the current one. It is called employee turnover. Researchers found a correlation between job satisfaction and employee turnover (Carsten, \& Spector, 1987). One of the most important functions of the human resource management is to retain the capable employees in the organization. For developing employees organizations invest huge resources (Kazi, \& Zadeh, 2011). But if the employees do not find satisfaction in their job they may not continue with their job. It is a very big loss for the organization in many ways. Firstly they lose their investment they made after the trained employees and secondly they lose the organizational capacity by losing the experienced employees.

\section{Variables Of Job Satisfaction / Dissatisfaction}

There are many reasons of employee's job satisfaction. In many cases some of them are very common while some of them are not much usual or obvious. It is commonly approved by the researchers that there are three common factors those make employees satisfied or dissatisfied. These are job characteristics, organization characteristics, and employee characteristics (Glisson \& Durick, 1988).

Job Characteristics includes several factors like job itself, pay and salary, working conditions, and so on (Smith et al., 1969). Some employees put more value the social issues for being satisfied and dissatisfied (Locke, 1976). In our study we have investigated the few of these factors like how much they like the job i.e. teaching, to what extent they are satisfied with the salary they receive, and how much status they are enjoying for their job.

In case of organizational characteristics, for being satisfied / dissatisfied with the job employees mostly look into the behavior of coworkers (Jex, 2002). So we have investigated this factor in our study. Another factor has been investigated as an organizational characteristic. That is the importance of the work experience to achieve the dream job. It is assumed that teaching in schools helps job candidates to solve the employment problems.

Some people are genetically positive to situations while some of them are negative to their situation. Positive or optimistic people always find some reasons to be satisfied with their job. They do not require much to make themselves satisfied. Researchers found that social factors have a significant influence over employees' job satisfaction (Baker, 2004). In this study, several social and personal factors are investigated to see the relationship of this factor on employee job satisfaction. Namely, these factors are - earning pocket money, passing transitional and getting engaged with social activity. All of these factors are relative to employees' personal characteristics.

In reality, some of the people are in need pocket money. They may not responsible for providing to their families but they need to earn their own pocket money. Some of the teachers, especially female ones, are 
passing transitional period before starting a conjugal life. They only want an identity so that they can produce an attractive bio-data for a settled marriage. On the other hand many educated house wives are only interested to get engaged to a social activity. This study investigated all these factors to have a conclusion. The variables give the teachers life satisfaction. It is found that there is a correlation between life satisfaction and job satisfaction (Tait et al., 1989). It is also found that there is a positive correlation between job satisfaction and engagement (Harter et al., 2002).

\section{Methodology}

This is a descriptive study for finding out the individual factor responsible for the job satisfaction of teachers who are working for different schools located in Sylhet City. Data have been collected from the respondent serving them close ended structured questionnaire applying a five point Likert Scale. These data are analyzed and presented through pie charts using SPSS. Sample of the study has been collected using cluster sampling method. It was possible to collect data from 87 teachers.

\section{Analysis And Interpretation}

It is found as a result of studies that female teachers are more satisfied than male teachers (Taylor and Tashakkori 1995). This study also indicates the same. Here, on chart - 1, it is shown that, $12.64 \%$ of the school teachers in Sylhet city are male and more than seven times of it, $87.36 \%$ of them are female. As a vital demographic factor of job satisfaction, this study has looked in to the marital status of the teachers and found $57.47 \%$ of the teachers are married.

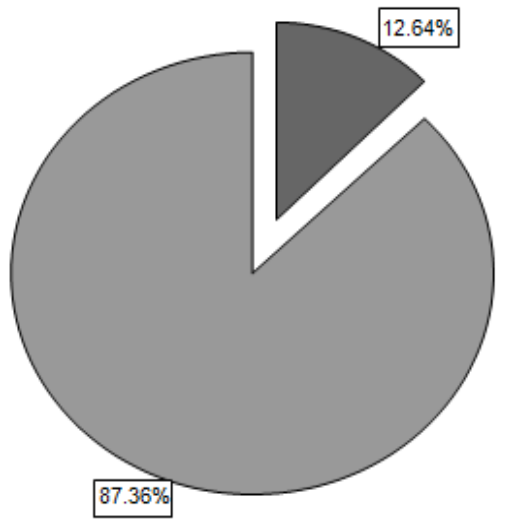

Chart-1: Gender of respondent

Age of an individual is another demographic factor that influences one's satisfaction on his /her job. Researchers found that older teachers are more stay able and try to improve working condition while the younger ones are more enthusiastic and change the job more frequently (Lowler, Gill, and Coppard 1985). Chart - 2 shows that the majority of the teachers are in between $20-30$. This age indicates that the just have completed their graduation and they still have the opportunity to find a dream job.
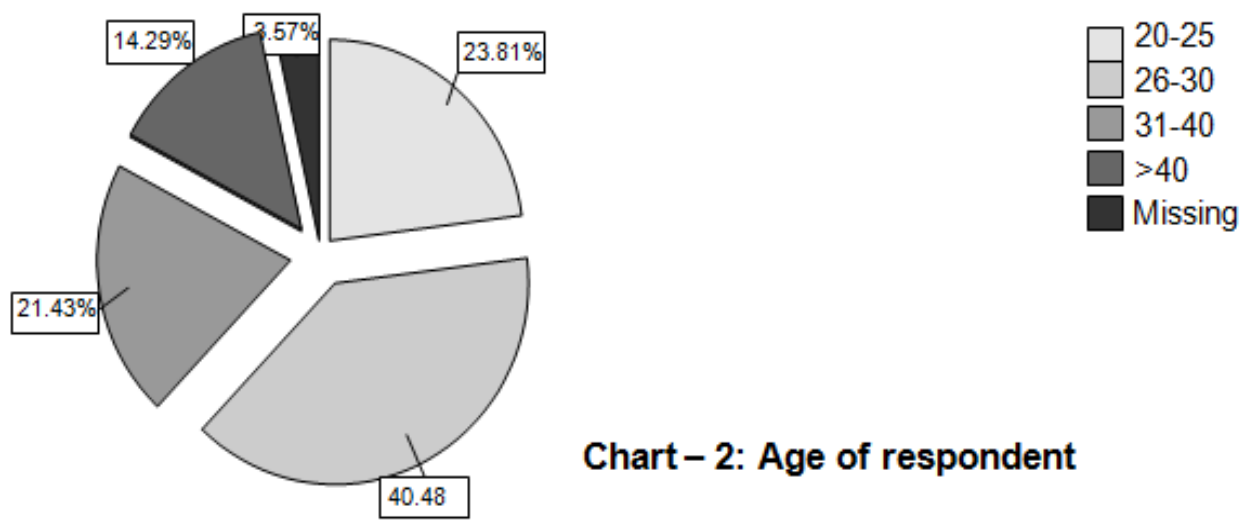

Another obvious demographic factor for teachers is the level of education. This study found that $63.22 \%$ of the teachers who work in different school in Sylhet city have completed their master degree in relevant subject. After analyzing the demographic factors, response of the respondents to the variables are analyzed. Very firstly, respondents were asked to response the statement "I like teaching". Al most $46 \%$ percent of them said they are "Strongly Satisfied". 


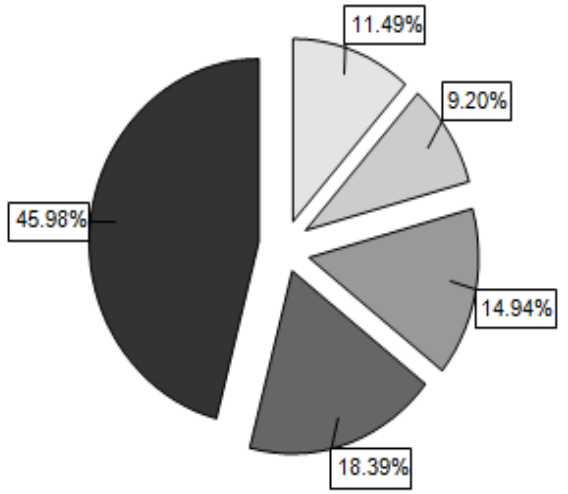

$\square$ Strongly Dissatisfied
$\square$ Dissatisfied
$\square$ Neutral
$\square$ Satisfied
$\square$ Strongly Satisfied

Chart-3: I like teaching

As money is one of the big sources of satisfying human needs, salary is one of the major factors of job satisfaction. But interestingly, this study, Chart -4 , shows that only $16 \%$ of the respondents are "Strongly Satisfied", $15 \%$ of the respondents are "Satisfied" while $30 \%$ of them are "Strongly Dissatisfied" and $14 \%$ of them are "Dissatisfied" with the statement "I am satisfied with my salary". In this study, the respondents were also asked to another statement "I work for earning pocket money". In this case, $40.20 \%$ of the respondents are "Strongly Satisfied" and $19.50 \%$ of them are "Satisfied".

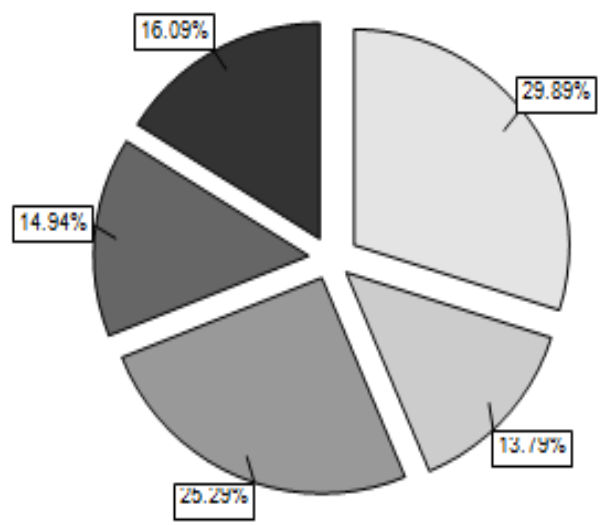

$\square$ Strongly Dissatisfied
$\square$ Dissatisfied
$\square$ Neutral
$\square$ Satisfied
$\square$ Strongly Satisfied

Chart -5 shows to response to the statement "This job increases my social status and network", $66.67 \%$ of the respondents of the study said that they are "Strongly Satisfied" with the statement while only $2.30 \%$ of the respondents said they are "Strongly Dissatisfied". There is another statement in this study for the respondents to response "I am satisfied for the relationship with my coworkers". To response to this statement teachers said none of them are "Strongly Dissatisfied" while $66.70 \%$ of them said that they are "Strongly Satisfied", $18.40 \%$ are "Satisfied". On the other hand, only $4.60 \%$ of them are "Dissatisfied".

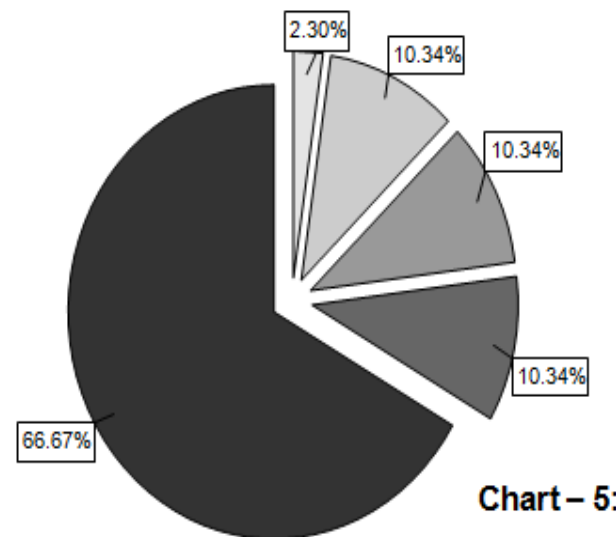

$\square$ Strongly Dissatisfied
$\square$ Dissatisfied
$\square$ Neutral
$\square$ Satisfied
$\square$ Strongly Satisfied

This study shows that nearly half, $47.13 \%$, of the respondents are "Strongly Satisfied" with the statement "I am passing my transitional period", while in Chart -6 , it is shown that $20.69 \%$ of the respondents are "Satisfied" with the statement. 


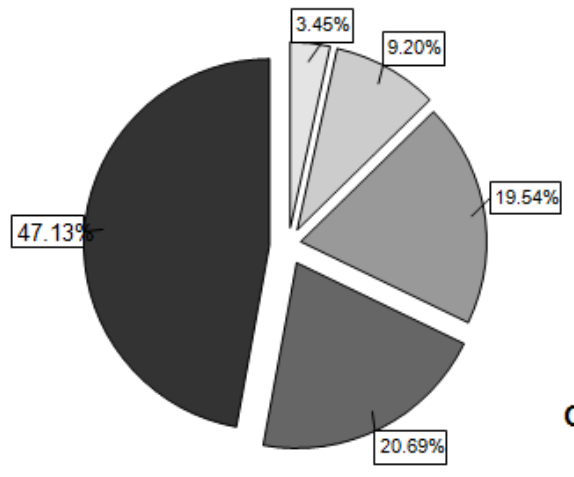

\author{
$\square$ Strongly Dissatisfied \\ Dissatisfied \\ Neutral \\ Satisfied \\ Strongly Satisfied
}

Chart-6: I am passing my transitional period

It is an interesting finding of the study that none of the respondent is "Strongly Dissatisfied" with the statement "Work experience of this job will help me to get my dream job / occupation". Only 2.3 percent of them are "Dissatisfied", $13.79 \%$ are "Neutral", $16.09 \%$ are "Satisfied", while $67.82 \%$ of them are "Strongly Satisfied".
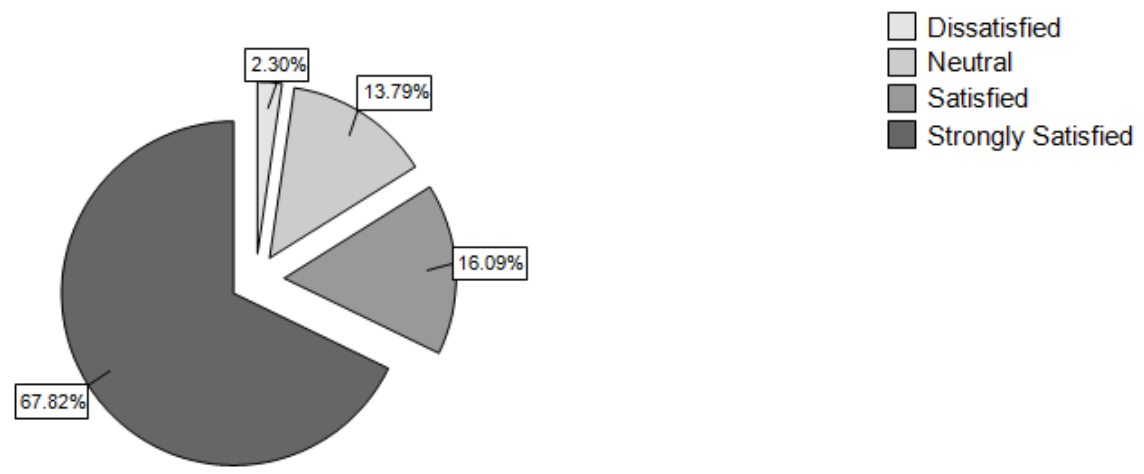

Chart-7: Work experience of this job will help me to get my dream job / occupation

Finally, Chart -8 shows that $64.37 \%$ of the respondents are "Strongly Satisfied" and $16.09 \%$ of them are "Satisfied" to work as a teacher to get engaged with a social activity.

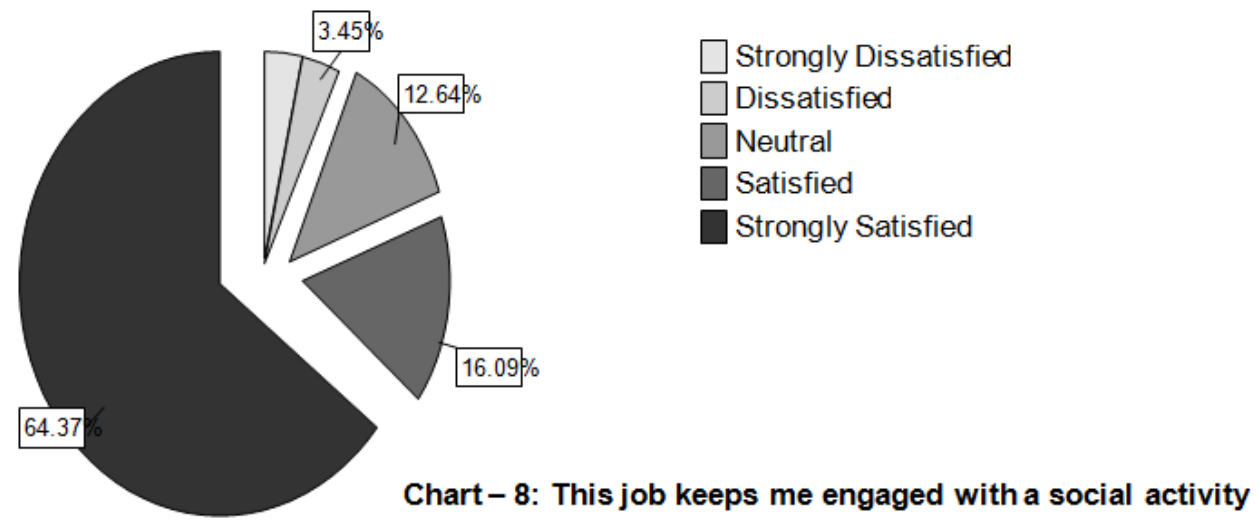

\title{
VIII. Discussion And Conclusion
}

Throughout this study we try to find out factors those influence school teachers to become and remain satisfied with their job. To discuss the findings of the study firstly the demographic characteristics of the respondents are looked in to. It is found that $87.40 \%$ of the respondents are female, $57.47 \%$ of the respondents are married, and $63.22 \%$ of the respondents have done their Master Degree. It is also found that nearly $65 \%$ of them are in between 20-30. From these demographic facts a picture of the demographic characteristics of the teachers may be drawn. Most of the teachers are highly educated young female and more than half of them are married.

Looking in to the variables it is found that $64.40 \%(46 \%+18.40 \%)$ of the responding teachers like their job. All over the world, teachers are the key personalities to discover the potential of the children and to make them ready to contribute the humanity and the civilization. That is why some people like to teach pupil to make them capable. Likewise, it may be said that most of the school teachers of the Sylhet city are satisfied for getting the opportunity to teach pupil. 
Factors Those Influence The Job Satisfaction of School Teachers Who Work for Different Schools...

One of the very first reasons for people to work is to satisfy their needs. Salary is one of the elements that help individuals to meet up their needs. In this study it is found that among the respondents only $31 \%$ $(14.90 \%+16.10 \%)$ are satisfied by their salary. But, still, nearly $60 \%$ percent of the respondents work for earning their pocket money. So, it would be said that though moneywise teachers are not satisfied to their job, some of them, still, work for earning their pocket money.

On the other hand, $77 \%(66.70 \%+10.30 \%)$ of the respondents are satisfied with the increase of their social status and identity. Interestingly, it is found that $83.90 \%(16.10 \%+67.80 \%)$ of the respondents are satisfied with the experience they are earning though doing the teaching job for achieving a dream job or occupation. And more interestingly, none of the respondents are in doubt of the usage of their experience. From these variables it would be interpreted that most of the teachers work to have a social status and identity and to collect the elements for making their dreamed future. It is mentionable that teaching in schools allows teacher to practice and solve the potential problems generally candidates face in several competitive employment tests. This job gives them good reference for the future career also.

$67.80 \%(20.70 \%+47.10 \%)$ of the respondents says they are passing their transitional period of life. Highly educated young people always have their dream achieve their goals. Before attaining the goal many potential people want to contribute the society. Finding these types of opportunity gives them pleasure. Sometimes, coworkers play very vital roles for satisfying individuals. Here, $85.10 \%$ of the respondents are satisfied with the relationship with their coworkers while none of them are dissatisfied.

Finally, more than $80 \%(16.10 \%+64.40 \%)$ of the respondents are satisfied doing the job as this job makes them engaged in a noble social activity. As it is shown that most of the teachers are highly educated young female and more than half of them are married. These potential housewives like to get engaged with some social activities. Teaching in schools is a perfect opportunity for them to have these types of opportunity.

To conclude it would be said that school teachers who work for different schools located in Sylhet city are not satisfied for the money they earn from their job. But, still, they find reasons for being satisfying themselves to their job. The major factors those influence these teachers' job satisfaction are the job i.e. teaching itself, the social status and identity, the usage of their work experience, the opportunity of passing transitional period will good colleagues, the opportunity to get engaged with social activity.

\section{References}

[1]. Abdul Karim, 1992: Corpus of the Arabic and Persian Inscriptions of Bengal, Asiatic Society of Bengal, Dhaka, 1992, 8, 58, 27073

[2]. Abu Iman 1967: 'Ancient Sylhet: History and Tradition' in Sylhet: History and Heritage, pp 173-202; also Chakrabarti, Ancient Bangladesh, pp 158-59. Kamalakanta Gupta, Copper-Plates of Sylhet, Lipika Enterprises, Sylhet, 1967.

[3]. Baker, W. K. (2004). Antecedents and consequences of job satisfaction: Testing a comprehensive model using integrated methodology. Journal of Applied Business Research, 20(3), 31-44.

[4]. Banglapedia: http://en.banglapedia.org/index.php?title=Sylhet_City_Corporation 19-Nov-16 14:36:24

[5]. Bowen, B. E., \& Radhakrishna, R. B. (1991). Job satisfaction of agricultural education faculty: A constant phenomena. Journal of Agricultural Education, 32 (2). 16-22.

[6]. Carsten, J. M., \& Spector, P. E. (1987) Unemployment, job satisfaction, and employee turnover: A meta-analytic test of the Muchinsky model. Journal of Applied Psychology, 72, 374-381.

[7]. Cheloha, R. S., \& Farr, J. L. (1980). Absenteeism, job involvement, and job satisfaction in an organizational setting Journal of Applied Psychology, 65(4), 467-473. doi: http://dx.doi.org/10.1037/0021-9010.65.4.467

[8]. Glisson, C., \& Durick, M. (1988). Predictors of job satisfaction and organizational commitment in human service organizations Administrative Science Quarterly, 33(1), 61-81.

[9]. Hattie, J. 2003, 'Teachers make a difference: What is the research evidence?' paper presented to Australian Council for Educational Research Annual Conference, Melbourne, 19-21 October.

[10]. Heller, D., Judge, T. A., Watson, D. (2002) The Confounding Role of Personality and Trait Affectivity in the Relationship between Job and Life Satisfaction Journal of Organizational Behavior 23, Pp 815-835.

[11]. Jex, S. M. (2002). Organizational psychology: A scientist-practitioner approach. New York, NY: John Wiley \& Sons, Inc.

[12]. Johns, G. (1997). Contemporary research on absence from work: Correlates, causes, and consequences. In C. L. Cooper \& I. T. Robertson (Eds.), International review of industrial and organizational psychology (Vol. 12, pp. 115-173) Chichester, UK: Wiley.

[13]. Jones, M.D. (2006). Which is a better predictor of job performance: Job satisfaction or life satisfaction Journal of Behavioral and Applied Management 15(6), 77-97?

[14]. Judge, T. A., \& Church, A. H. (2000) Job satisfaction: Research and practice. In C. L. Cooper \& E. A. Locke (Eds.), Industrial and organizational psychology: Linking theory with practice (pp. 166-198). Oxford, UK: Blackwell.

[15]. Judge, T. A., \& Klinger, R. (2007) Job satisfaction: Subjective well-being at work. In M. Eid, \& R. Larsen (Eds.), The science of subjective well-being (pp. 393-413). New York, NY: Guilford Publications.

[16]. Katy Gardner, 1995: Global Migrants, Local Lives: Travel and Transformation in Rural Bangladesh, Clarendon Press, Oxford, 1995, pp 75-76

[17]. Kazi, G., \& Zadeh, Z. (2011) The Contributions of Individual Variables: Job Satisfaction and Job Turnover. Interdisciplinary Journal of Contemporary Research in Business Retrieved from http://journal-archieves8.webs.com/984-991.pdf

[18]. Landy, F. J. (1978). An opponent process theory of job satisfaction Journal of Applied Psychology, 63(5), $533-547$.

[19]. Locke, E. A. (1976). The nature and causes of job satisfaction. In M. D. Dunnette (Ed.), Handbook of industrial and organizational psychology (pp. 1297-1349) Chicago, IL: Rand McNally.

[20]. Lowther, M. A., Gill, S. J., Coppard, L. C. (1985). Age and the Determinants of Teacher Job Satisfaction The Gerontologist, Vol. $25,5,520-525$.

[21]. Naidu, S. P. (1996). Public administration: Concepts and theories. Hyderabad, India: New Age International, Ltd. Publishers. 
[22]. Noordin F, Jusoff K (2009). Levels of Job Satisfaction amongst Malaysian Academic Staff Asian Soc. Sci. 5:5.

[23]. Smith, P. C., Kendall, L. M., \& Hulin, C. L. (1969) Measurement of satisfaction in work and retirement Chicago, IL: Rand McNally.

[24]. Spector, P. E. (1997). Job Satisfaction: Application, Assessment, Causes, and Consequences. Thousand Oaks: Sage Publications, Inc.

[25]. Tait, M., Padgett, M.Y., \& Baldwin, T.T. (1989) Job and life satisfaction: A reexamination of the strength of the relationship and gender effects as a function of the date of the study Journal of Applied Psychology, 74, 502-507.

[26]. Taylor, D. L., Tashakkori, A. (1995). Decision Participation and School Climate as Predictors of Job Satisfaction and Teachers' Sense of Efficacy Journal of Experimental Education, 63, 3, 217 - 230

[27]. Wu, Z. 2010: Factors that motivate teachers in profitmaking schools. (Thesis). University of Hong Kong Pokfulam, Hong Kong SAR. Retrieved from http://dx.doi.org/10.5353/th_b5017717 19-Nov-16 15:23:22 